\title{
KONSEP KALKI AWATARA DALAM KITAB WEDA Perspektif Dr. Pandit Vedaprakash Upaddhay dalam Buku Muhammad in The Hindu Scriptures
}

\author{
Hendrik Alim Mashuri \\ Fakultas Ushuluddin UIN Sultan Syarif Kasim Riau \\ e-mail: hendrikalimm@,uin-suska.ac.id \\ Abu Bakar \\ Fakultas Ushuluddin UIN Sultan Syarif Kasim Riau \\ e-mail: abubakar@uin-suska.ac.id \\ Suja'i \\ Fakultas Ushuluddin UIN Sultan Syarif Kasim Riau \\ e-mail:sujai@uin-suska.ac.id
}

\begin{abstract}
Abstrak
Penelitian ini ingin menjelaskan tentang konsepsi Kalki Awatara dalam Kitab Weda. Pertayaan yang diajukan dalam penelitian ini adalah (1) Bagaimana pemahaman umat hindu tenatng kalki awatara dalam tinjauan dr. Ved prakas? dan (2) Bagaimana menurut perspektif Dr. Ved Prakash Upaddhay terhadap kalki awatara tentang keingkarnasian nabi mubammad dalam buku mubammad in the Hindu Scriptures? Penelitian ini termasuk jenis penelitian pustaka (library research), penelitian ini penulis menggunakan studi kepustakaan (library research), sebab data-data yang digunakan adalah material tertulis seperti buku-buku, artikel, dan lain-lain yang berhubungan dengan topik pembahasan. Hasil penelitian menunjukean babwa 'Brahma' sebenarnya adalab Ibrabim, di mana huruf awal A dalam Abraham dipindahkan ke bagian akhir menjadikannya Brahma. Analisis ini akurat ketika seseorang menulis dua kata dalam aksara Arab, bahasa yang mirip dengan yang diucapkan oleb Nabi Ibrahim. Demikian pula, istri pertama Ibrahim, Sarah, disebutkan dalam Weda sebagai Saraswati, dan Nabi Nub (Nub Air Bab) disebutkan sebagai Manub atau Manu Beberapa Pakar menganggap Atharva $V$ eda sebagai Kitab Abraham. Nabi Ismail (Ismail) dan Ishaq (Ishak) masing-masing bemama Atharva dan Angira, dalam Weda. Diketahui dengan baike babwa umat Hindu menyukai penyembahan pablawan, dan masuk akal untuk mengasumsikan bahwa dalam jangka waktu yang lama, penghormatan dan penghormatan yang tinggi bagi beberapa Nabi menyebabkan beberapa dari mereka dianggap sebagai tuban atau Tuhan. Lebih lanjut, kemungkinan besar Kitab Ibrabim dan kitab para Nabi lainnya berisi nubuatan tentang Nabi Terakhir, Mubammad (s). Sejarawan Muslim India berpendapat bahwa kuburan Nabi Sheesh dan Ayyub (Ayyub) berada di Ayodbya, di provinsi Uttar Pradesh, India. Di zaman kuno, Ayodbya dikenal sebagai Khosla menurut Shatpath Brabmanas.
\end{abstract}

Kata Kunci: Brahma, Kalki Awatara, Kitab Weda

\section{Pendahuluan}

Kemajemukan Tuhan dalam Agama Hindu telah membawa persepsi yang beragam. Hal ini dipicu oleh banyaknya Simbolisasi Sang Pencipta yang dipuja dan disembah oleh umat Hindu secara turun 
temurun dalam konteks Awatara (Chudamani, 2013:51). Awatara dalam agama Hindu diyakini sebagai penjelmaan Tuhan yang turun ke dunia kapanpun Tuhan turun ke bumi, yang tidak bisa dilaksanakan oleh manusia biasa, untuk melaksanakan fungsi khusus dan bertujuan untuk menyelamatkan para penyembahnya dan membinasakan orang-orang jahat. Dalam buku yang ditulis oleh Tim Penyusun Hanuman Sakti (2012: 1-3), dikatakan sebagai berikut:

\begin{tabular}{|c|}
\hline $\begin{array}{l}\text { Kapanpun dan di } \begin{array}{r}\text { manapun } \\
\text { pelaksanaan dharma } \\
\text { (=kebaikan, }\end{array} \\
\text { kebajikan, lawan dari adhama } \\
\text { keburukan, kejahatan) mengalami } \\
\text { kemerosotan dan hal-hal yang } \\
\text { bertentangan dengan dharma mulai } \\
\text { merajalela, pada waktu itulah Aku } \\
\text { sendiri menjelma, Wahai putra } \\
\text { keluarga Bharata. } \\
\text { menyelamatkan Ontuk } \\
\text { membinasakan orang saleh, } \\
\text { menegakkan kembali prinsip-prinsip } \\
\text { dharma dan Aku sendiri muncul pada }\end{array}$ \\
\hline
\end{tabular}

Dikatakan bahwa Awatara adalah

Tuhan yang menjelma sebagai manusia, yang menjadi guru dari segala guru, dan di antara tanda- tanda yang memungkinkan seseorang mengenal sosok Awatara, yang paling jelas di antaranya adalah "siddh?" yaitu kekuatan adikodrati atau super normal, karena ia manunggal sepenuhnya dengan Tuhan, sehingga memiliki kemampuan yang luar biasa tidak bisa diikuti oleh pikiran dan membuat apa saja sesuai kehendaknya, tanpa belajar tanpa menggunakan mantra.

Seorang Maha Resi yang sudah tinggi tingkatannya biasanya juga memiliki kemampuan yang luar biasa, akan tetapi kalau sering dipertunjukkanya akan menjadi punah, lama lama kemampuannya akan hilang. Berbeda dengan seorang Awatara, ia tidak perlu belajar yoga, kekuatannya sudah ada sejak lahir, dan tidak pernah punah karena siddhi itu adalah alamnya, walaupun sering digunakan. Siddhi seorang Awatara tidak mempunyai motif pamer atau mencari keuntungan materi maupun nama dan selalu digunakan untuk yang bermanfaat. Seorang Awatara juga memiliki kemampuan bisa melihat masa lalu, masa sekarang dan masa yang akan datang, walaupun lahir berwujud manusia tetapi beliau tidak bisa disamakan dengan manusia biasa.

Seorang Awatara baru turun ke dunia kalau keadaan sudah buruk, kejahatan merajalela Hukum Agama dilanggar dan itulah disebut jaman kali (Chudamani, 2013:52). Di dalam Bhagawad-gita disebutkan sebagai berikut:

Ajo 'pisan avyayatma bhutanam iswaro
"psan prakritim svam Adhisthaya
sambhavamy atmamayaya' (Chudamani,
2013:53).
(walaupun Aku tak terlahirkan,
tak termusnahkan dan Aku adalah
pencipta mahluk hidup, segala nama-
Ku atas penguasaan sifat-Ku sendiri


dan dengan kekuatan maya-Ku menjelma).

Yada yada hi dharmasya glanir bhavati bharata abhjutthanam adharmasya tada 'tmanam srijamy aham (Chudamani, 2013:53).

(manakala dharma hendak sirna, dan adharma hendak merajalela saat itu Wahai keturunan Bharata, Aku sendiri turun ke dunia.

Sebagai perwujudan Tuhan yang

Maha kasih-Nya tak terbatas, Awatara diturunkan ke dunia untuk menolong umat manusia, agar terhindar dari bencana pralaya (kiamat). Apabila dunia sudah terancam malapetaka, maka Tuhan mengutus seseorang yang telah mencapai tingkatan moksa turun ke dunia untuk menegakkan dharma dari tantangan adharma. Sang Hyang Widhi atau Tuhan Yang Maha Esa yang bersifat Maha Pengasih dan Penyayang turun ke dunia dengan perwujudan tertentu untuk menyelamatkan umat manusia dari cengkraman bahaya. Perwujudan Sang Hyang Widhi atau Tuhan Yang Maha Esa yang turun ke dunia untuk membasmi kejahatan serta membangkitkan kebenaran disebut Awatara (Chudamani, 2013:54).

Awatara dalam perspektif agama Hindu, dikenal ada sepuluh macam Awatara dan fungsinya sebagai penjelmaan atau Inkarnasi Tuhan Yang Maha Esa ke dunia untuk menegakkan dharma dan memberantas adharma sebagai berikut (Soekmono, 2012: 29-30):
1. Mastya Awatara adalah: sosok makhluk yang berwujud sebagai ikan yang menolong manusia pertama untuk menghindarkan diri dari air bah yang menelan dunia.

2. Kurma Awatara adalah: sosok makhluk yang berwujud ebagai kura-kura yang berdiri di atas dasar laut dasar laut yang menjadi alas bagi gunung mandara yang dipakai oleh para Dewa untuk mengacaukan lautan dalam usaha mendapatkan air penghidup.

3. Waraha Awatara adalah: sosok makhluk yang berwujud sebagai Babi hutan dan mengangkat dunia ke tempatnya. Ketika dunia ditelan laut dan ditarik ke dalam kegelapan.

4. Narasimbha Awatara adalah: sosok makhluk yang dikenal sebagai singamanusia yang membunuh Hiranyakasipu seorang raksasa, dan menguasai dunia. Kesaktiannya yang luar biasa menjadikan tidak dapat dibunuh oleh Dewa, manusia maupun binatang.

5. Wamana Awatara adalah: sosok manusia kerdil yang sangat lalim memerintah dunia supaya kepadanya diberikan tanah seluas tiga langkah. Setelah diizinkan, maka dengan tiga langkah menguasai dunia, angkasa dan sorga. Dunia dengan tiga langkahnya; 
waktu terbit, tengah hari, dan terbenam.

6. Parasurama Awatara adalah: sosok manusia yang dikenal sebagai Rama bersenjata kapak dan menggempur golongan satria sebagai balas dendam terhadap penghinaan yang dialami ayahnya.

7. Rama Awatara adalah: sosok manusia yang dikenal sebagai titisan Wisnu yang terkenal dari Ramayana yang mengancam keselamatan dunia Rawana

8. Krisna Awatara adalah: sosok manusia yang merupakan titisan Wisnu yang terkenal dari Mahabharata, sebagai raja yang membantu para Pandawa menuntut keadilan dari para kaurawa.

9. Budha Awatara adalah: sosok manusia suci yang diturunkan ke duinia untuk menyiarkan agama palsu guna menyesatkan dan melemahkan yang memusuhi para Dewa.

10. Kalki Awatara adalah sosok manusia penjelmaan atau Inkarnasi Tuhan Yang Maha Esa ke dunia untuk menegakkan dharma dan memberantas adharma, yang menunggangi kuda putih dan membawa pedang terhunus yang menegakkan kembali keadilan dan kesejahteraan di atas dunia ini. Keadaan dunia sudah buruk sekali sehingga dunia terancam kemusnahan.
Ketika membahas tentang Awatara yang kesepuluh yang dikenal dengan sebutan Kalki Awatara, menurut Pandit Vedaprakash Upadhai, seorang professor beragama Hindu berasal dari India dari kasta Bengali, ilmuwan dan peneliti seorang Pandit terkenal di Universitas Allahabad, mengklaim bahwa deskripsi tentang Kalki Avatar yang terdapat dalam kitab suci agama Hindu adalah salah satu awatara Wisnu (awatara Wisnu, yang termasuk didalamnya adalah Khrisna) sekaligus yang terakhir dan yang paling hebat, yang akan muncul pada akhir zaman Kaliyuga (zaman kegelapan, kebodohan, dan kehancuran). Nama kalki seringkali dipakai sebagai metafora untuk kekekalan dan waktu yang bisa berarti kemunculannya akan menjadi sebuah misi yang kekal hingga akhir dunia/waktu. sebenarnya.

Setelah bertahun-tahun mengadakan penelitian, Pandit Vedaprakash Upadhai menerbitkan buku tentang Kalki Awatara dan delapan pandit lain telah mendukung dan menyatakan noktah-noktah argumennya adalah sahih. Menurut kepercayaan Hindu dan kitab-kitab suci mereka, deskripsi pembimbing dan pemimpin, yang dinamakan Kalki Awatara, hanya cocok dengan Nabi Muhammad SAW., yang dilahirkan di Mekkah. Dia 
menyinggung kepada fakta bahwa orangorang Hindu di seluruh dunia seharusnya tidak menanti lebih lama lagi kedatangan Kalki Awatara (Sang Ruh) dan harusnya lebih mudah menerima Nabi Muhammad SAW., sebagai Kalki Awatara. Fakta-fakta tersebut telah diuji dan didukung oleh delapan pandit terkemuka berdasarkan keterangan-keterangan berikut dari kitab suci Veda dan kitab-kitab suci agama Hindu lainnya yang mendukung klaimnya itu.

Dalam Purana (kitab suci kaum Hindu) dikatakan bahwa Kalki Awatara adalah seorang utusan (nabi) Allah yang terakhir di dunia ini guna membimbing seluruh dunia dan seluruh makhluk manusia. Menurut suatu prediksi agama Hindu, kelahiran Kalki Awatara, akan terjadi di suatu semenanjung yang sekali lagi menurut agama Hindu adalah kawasan Arab. Dalam kitab-kitab kaum Hindu, nama ayah dan ibu Kalki Awatara yang diberikan kepada mereka masing- masing adalah Vishnubhagat dan Sumaani.

Seandainya kita memeriksa makna nama-nama ini kita akan sampai kesimpulan yang menarik: Vishnubhagat $=$ Vishnu (berarti Allah) + Bhagat (berarti hamba $)=A l l a b+A b d$ (dalam bahasa Arab) $=$ hamba Allah $=$ Abdullah (dalam Bahasa Arab) (nama dari ayah
Muhammad). Sumaani $=$ kedamaian atau tenangan $=$ Aminab (dalam bahasa Arab) (ibu Nabi Muhammad). Dalam kitab- kitab agama Hindu, disebutkan bahwa makanan pokok adalah kurma dan minyak zaitun dan ia orang yang paling jujur dan setia di kawasan tersebut. Tanpa keraguan apapun Nabi Muhammad SAW., dinyatakan memiliki kualitas-kualitas ini.

Dinyatakan dalam Veda (kitab suci agama Hindu) bahwa kelahiran Kalki Awatara terjadi pada suku terhormat. Secara sempurna ini hanya cocok pada bangsa Quraisy di mana Nabi Muhammad SAW., memilikinya. Allah akan mengajar Kalki Awatara melalui utusan-Nya (malaikat) di sebuah gua. Allah mengajar Nabi Muhammad SAW., melalui malaikatNya, Jibril, di sebuah gua yang dikenal sebagai gua Hira. Allah akan membantu Kalki Awatara dengan seekor kuda yang berkecepatan tinggi untuk naik dan mengelilingi dunia dan tujuh langit. Indikasi kepada Buraaq (kuda) dan mi'raj (malam ketika Nabi menembus tujuh langit. Allah juga akan membantu Kalki Awatara dengan pertolongan ilahi. Ini khususnya terbukti dalam Perang Uhud. Laporan lain yang mempesonakan yang membicarakan tentang Kalki Avatar adalah bahwa ia akan dilahirkan pada tanggal 12 dari sebuah bulan. Sedangkan Nabi 
Muhammad SAW., dilahirkan pada 12 Rabiul Awwal 571 M. Kalki Awatara adalah seorang penunggang kuda yang hebat dan seorang jago pedang.

Namun demikian, walaupun sudah ada klaim, pernyataan dan publikasi hasil penelitian dari seorang Professor beragama Hindu yang didukung oleh delapan pandit terkemuka berdasarkan keterangan- keterangan berikut dari kitab suci Veda dan kitab-kitab suci agama Hindu lainnya yang menyatakan bahwa deskripsi tentang Kalki Avatar yang terdapat dalam kitab suci agama Hindu sebenarnya adalah Nabi Muhammad SAW., akan tetapi kenyataan ini tidak serta merta dapat diterima dan diakui bahkan dibantah oleh penganut agama Hindu baik di India itu sendiri maupun penganut Hindu di Indonesia. Beberapa pernyataan menolak dan bantahan dari penganut Hindu di Indonesia, di antaranya adalah tulisan Bumi Tanaya Suastika berjudul "Nabi Muhammad Bukan Kalki Avatar," sebagai berikut:

Akhir-akhir ini banyak sekali milis maupun forum diskusi di internet yang mengklaim bahwa Nabi Muhammad adalah Kalki Awatara. Sebenarnya itu salah besar. Kalki Awatara merupakan awatara terakhir yang diramalkan oleh umat Hindu sebagai penyelamat dunia terakhir/kesepuluh sebelum terjadi peleburan/pralaya/kiamat. Awatara sebelumnya yaitu Krisna dan Budha.
Pernyataan menolak dan bantahan yang senada dengan kutipan di atas, juga disampaikan oleh Jro Mangku Suardhana, dalam tulisannya berjudul: "Hindu Menjawab: Kalki Awatara Bukanlah Nabi Muhammad." Dalam artikel ini penulis akan membahas sedikit saja tentang perbedaan antara Nabi dengan Awatara karena akhir-akhir ini banyak sekali milisi ataupun forum diskusi di medsos yang mengklaim bahwa Nabi Muhammad adalah Kalki Awatara, yang sesungguhnya hal itu adalah salah besar. Mari kita ulas beberapa saja dan tidak perlu menyeluruh, hingga jelas dapat kita bedakan bahwa Nabi Muhammad bukanlah Kalki Awatara.

Ketahuilah: Jelas umat Islam menyatakan bahwa Nabi Muhammad Shallallahu 'Alaibi Wasallam (bahkan tarmasuk para Nabi yang lainnya) adalah Utusan Allah (Tuhan) bukan Allah, seperti yang tersurat dalam kalimat Syahadat berikut: "Asybadu anna Mubammadar Rasunlullaab" artinya "Aku bersaksi babwa Muhammad adalah utusan Allab". "Tidaklah Aku menciptakan jin dan manusia melainkan untuk beribadab kepada- Ku." (QS. al Dzariyat: 56). Sementara umat Hindu meyakini Awatara itu adalah Manifestasi Hyang Widhi (Tuhan) sendiri yang 
menjelmakan diri-Nya ke dunia untuk menyelamatkan umat dan dunia, maka Awatara bukan Utusan atau Nabi-(Awatara Purana) dan seseungguhnya Hindu sendiri punya Utusan Tuhan (Nabi) namanya para Rsi bukan Awatara.

Ketika beberapa penganut Hindu di Indonesia menolak dan membantah klaim, pernyataan dan publikasi hasil penelitian dari seorang Professor beragama Hindu yang didukung oleh delapan pandit terkemuka berdasarkan keteranganketerangan berikut dari kitab suci Veda dan kitab-kitab suci agama Hindu lainnya yang menyatakan bahwa deskripsi tentang Kalki Avatar yang terdapat dalam kitab suci agama Hindu sebenarnya adalah Nabi Muhammad SAW., justeru Dewa Putu Sutrisna, seorang anak Pendeta Tertinggi Hindu Bali menyatakan dirinya untuk memeluk Islam karena meyakini bahwa Kalk Awatara adalah benar-benar Nabi Muhammad SAW., sesuai dengan cirri-ciri dan karakteristik yang tertera dalam Kitab Wedanya.

\section{Kelahiran dan Penyebarannya di India}

Agama Hindu adalah suatu agama yang bersumber dan berkembang di bumi India. Kata Hindu berasal dari nama sungai Indus yang melewati daerah barat bumi India. Orang-orang pertama menyebutnya sungai Sindhu dan berubah menjadi Hindu (Pembina Kerohanian Hindu Budha Disbintalad, 2013:11) Agama Hindu pertama kali berkembang di lembah sungai Sindhu sekitar 6.000 tahun sebelum Masehi sebagai agama tertua, agama Hindu kemudian berkembang ke berbagai wilayah dunia, termasuk Asia Tenggara dan Indonesia (Pembina Kerohanian Hindu Budha Disbintalad, 2013:11).

\section{Zaman Weda Kuno (2.500 SM - 1000 SM)}

Pada zaman +1000 SM Bangsa Arya datang ke India dengan menempati daerah Punjab (daerah lima aliran sungai), yaitu sungai Hindus atau Sindhus. Bangsa Arya ini serumpun dengan bangsa Jerman, Yunani, dan Romawi sehingga mereka disebut sebagai rumpun bangsa IndoJerman

\section{Zaman Brahmana (1000 SM - 750 SM)}

Zaman ini ditandai dengan adanya kitab-kitab Brahman yaitu bagian dari Weda yang berisi tentang peraturan dan kewajiban keberagamaan. Di zaman ini sajian- sajian atau kurban menjadi lebih penting. Sajian atau kurban bukan sekedar untuk memohon pada dewa, tetapi sebagai alat untuk memaksa dewa-dewa memberikan kekuasaan kepada siapa yang melakukan sesajen (Rasyidi, 2011:55). 
Perkembangan agama Hindu pada zaman Brahmana ini merupakan peralihan dari zaman Weda Samhita ke zaman Brahmana.

\section{Zaman Upanisad (750 SM - 500 SM)}

Kata Upanisad berarti duduk di bawah kaki guru untuk mendengarkan ajarannya. Pada awalnya kata ini digunakan untuk menyebutkan ajaran yang diberikan oleh guru pada muridnya, tetapi kemudian dipergunakan untuk menyebutkan segala sesuatu yang bersifat mistik. Akhirnya kitab- kitab yang memuat ajaran ini juga disebut Upanisad

\section{Sumber Ajaran/ Kitab Suci Agama Hindu}

Setiap agama pasti mempunyai sumber ajaran atau sumber yang dijadikan hukum untuk dianut dan dijadikan pedoman dalam kehidupannya. Begitu juga agama Hindu ini, bahwa kitab atau sumber agama hindu adalah kitab suci Weda. Kitab itu terdiri atas beberapa kelompok kitab yang mempunyai nilai-nilai sendirisendiri

Asal-usul dan Perkembangan Awatara

Bagi penganut agama Hindu Awatara diyakini sebagai penjelmaan Tuhan yang diutus ke dunia sebagai pengejewantaan dari sifat Maha KasihNya yang tak terbatas melalui seseorang yang telah mencapai tingkatan moksa, untuk menolong umat manusia agar terhindar dari bencana/ malapetaka pralaya (kiamat) dan melaksanakan fungsi khusus dan bertujuan untuk menyelamatkan para penyembahnya dan untuk membinasakan orang-orang jahat.

Kitab Weda Ditinjau Dari Perspektif Prof. Pandit Vedaprakash Upadhai

1. Weda menyebutkan bahwa "kalki autar" akan menjadi Utusan / Nabi terakhir Bhagwan (Allah) untuk membimbing keseluruhan dunia. Setelah mengutip referensi ini, Pundit Parkash mengatakan bahwa ini menjadi kenyataan hanya dalam kasus Muhammad (saw).

2. Menurut nubuatan Hindu, "kalki autar" akan lahir di sebuah pulau \& itulah wilayah Arab yang dikenal dengan "Jazeeratul Arab".

3. Dalam kitab 'suci' Hindu nama ayah 'kalki autar' disebutkan sebagai 'Wisnu Bhagat' \& nama ibunya sebagai 'Somanib'. Dalam bahasa Sansekerta, 'vishnu' adalah singkatan dari Allah Subhana Wa Taala \& arti harfiah dari 'bhagat' adalah budak. Oleh karena itu, "Wisnu Bhagat" dalam bahasa Arab berarti hamba Allah (AbdAllah). 
'Somanib' dalam bahasa Sansekerta berarti damai \& tenteram yang dalam bahasa Arab dilambangkan dengan kata 'Amina'. Sedangkan nama ayah \& ibu Rasulullah SAW yang terakhir adalah AbdAllah \& Amina masingmasing.

4. Dalam kitab-kitab besar agama Hindu disebutkan bahwa 'kalki autar' akan hidup dari zaitun \& kurma \& dia akan jujur pada perkataannya \& jujur. Dalam hal ini Pundit Prakash menulis, "Ini benar \& ditetapkan hanya dalam kasus Muhammad (saw)."

5. Veda menyebutkan bahwa 'kalki autar' akan lahir di dinasti terhormat \& mulia di negerinya. Dan ini juga berlaku untuk Muhammad (saw) karena dia lahir di suku Quraisy yang dihormati dan mendapat tempat tinggi di Mekah.

6. kalki autar' akan diajarkan di gua oleh Bhagwan melalui utusannya sendiri. Dan memang benar dalam hal ini. Muhammad (saw) adalah satu-satunya orang di Mekah yang diajar oleh utusan Allah Jibril di gua Hira.

7. Ada tertulis dalam buku-buku yang diyakini umat Hindu bahwa Bhagwan akan memberikan 'kalki autar' dengan kuda tercepat \& dengan bantuan yang akan dia tunggangi keliling dunia \& tujuh langit / langit. Menunggangi 'Buraq' \& 'Miraj' oleh Nabi Muhammad (saw) membuktikan apa?

\section{Penyajian dan Analisa Data}

Diketahui dengan baik bahwa umat Hindu menyukai penyembahan pahlawan, dan masuk akal untuk mengasumsikan bahwa dalam jangka waktu yang lama, penghormatan dan penghormatan yang tinggi bagi beberapa Nabi menyebabkan beberapa dari mereka dianggap sebagai tuhan atau Tuhan. Lebih lanjut, kemungkinan besar Kitab Ibrahim dan kitab para Nabi lainnya berisi nubuatan tentang Nabi Terakhir, Muhammad (s). Sejarawan Muslim India berpendapat bahwa kuburan Nabi Sheesh dan Ayyub (Ayyub) berada di Ayodhya, di provinsi Uttar Pradesh, India. Di zaman kuno, Ayodhya dikenal sebagai Khosla menurut Shatpath Brahmanas.

Beberapa Pakar sekarang mulai menolak Purana hanya karena mereka menemukan di dalamnya banyak nubuatan dan tanda-tanda yang jelas dari kebenaran Nabi Muhammad. Sebuah kasus telah dibuat bahwa Purana yang sekarang bukanlah koleksi yang sama dengan yang dirujuk Weda dan kitab yang sebenarnya telah hilang. Meski demikian, anggapan ini tidak benar. Mustahil bahwa semua Purana 
yang telah dibaca dan dipelajari dengan seksama, bisa terlupakan dan musnah total, sedangkan Weda, yang hanya bisa dibaca dan dimengerti oleh sedikit orang, tetap utuh sampai sekarang Argumen lain yang menentang nubuatan tersebut adalah bahwa ini ditambahkan ke Purana di kemudian hari. Meski demikian, argumen ini juga tanpa dasar. Buku yang begitu terkenal, beredar luas dan dibaca pada waktu yang ditentukan dalam doa, tidak dapat dengan mudah dirusak. Terlebih lagi, semua Pandit dan ulama terpelajar dari Hindu tidak bisa bersekongkol dan diamdiam menambahkan nubuatan ini ke Purana. Hal yang paling aneh adalah bahwa korupsi itu dilakukan demi kepentingan Nabi dan bertentangan dengan agama mereka sendiri.

Semua kitab utama umat Hindu bemubuat tentang Nabi Muhammad. Selain banyak kualitasnya, peristiwa kehidupannya, Ibrahim, ka "bah, Bakkah (Makkah) dan Arab, nubuat menyebutkan namanya sebagai Mahamad, Mamah, dan Ahmad. Nama Mahamad muncul di Purana, Mamah di Kuntap Sukt (di Atharva Veda) dan Ahmad di Sama Veda. Banyak klasifikasi berbeda mengenai tingkat pentingnya Weda telah dibuat.

Misalnya, dalam Shatpath disebutkan bahwa Sama Veda adalah inti dari semua Veda. Di tempat lain di Taittiriya Brahmana, dinyatakan bahwa "Dunia ini diciptakan dari Brahma, Vaishas diciptakan dari mantra Rig Veda, Kashtriya diciptakan dari Yajur Veda dan Brahmana diciptakan dari Sama Veda."

\section{Kesimpulan}

Ilmu pengetahuan telah menyebabkan kerusakan bencana proporsi dengan meledakkan bomatom, dan karena itu tidak dapat digunakan untuk damai tujuan dalam sikap hormat bangsa. Hanya agama persatuan dapat membawa bangsa bersama-sama. Itu sebabnya, saya telah menggantungkan saya harapan pada beragama toleransi dan pemahaman sebagai substrat untuk upaya perdamaian.

Akan menentang tanya. Satusatunya orang yang will menolak tersebut upaya mereka yang adalah sangat berarti dan narrow berpikiran. Meskipundemikian, jika mereka datang dari mereka prasangka dan mengamati dunia tanpaperasaan, maka mereka akan mulai membenci mereka sempit pandangan sendiri. Saya telah memulai atas menulis dan menerbitkan bukuini, dengan maksud menyebarkan pesan Allah, yang, saya sungguh-sungguh percaya telah mengilhami saya untuk melakukannya. Hal ini tidak sangat jelas jika orang lain telah dilakukan ini tugas 
sebelumnya. Namun, sebuah buku berjudul Sarware Alam oleh Mohammad Muslim (diterbitkan oleh Jayyad Press, Kishanganj, Delhi, 1960) telah mengisyaratkan fakta bahwa Kalki Avatar tidak lain adalah Muhammad. Saya sangat percaya bahwa ini publikasi akan akhirnya mencapai terbukahati individu baik di dalam negeri dan seluruh di dunia.

Saya bersikeras bahwa ini telah ditulis dengan bantuan Allah. Subyek yang dibahas di sini tidak pribadi pendapatsaya. Mereka telah dipastikan dari Vedas dan Psurana. Selain itu, mereka adalah ekspresi dari spiritual inspirasi saya yangterima dari Tuhan. Komperatif, yaitu: membandingkan ide, pemikiran dan pendapat yang satu dengan yang lain tentang hal yang sama, baik yang memiliki nuansa pemikiran yang hampir sama atau bahkan yang sangat bertentangan.

Allah, yang, saya sungguh-sungguh percaya telah mengilhami saya untuk melakukannya. Hal ini tidak sangat jelas jika orang lain telah dilakukan ini tugas sebelumnya. Namun, sebuah buku berjudul Sarware Alam oleh Mohammad Muslim (diterbitkan oleh Jayyad Press, Kishanganj, Delhi, 1960) telah mengisyaratkan fakta bahwa Kalki Avatar tidak lain adalah Muhammad. Saya sangat percaya bahwa ini publikasi akan akhirnya mencapai terbuka- hati individu baik di dalam negeri dan seluruh di dunia. Saya bersikeras bahwa ini telah ditulis dengan bantuan Allah. Subyek yang dibahas di sini tidak pribadi pendapatsaya. Mereka telah dipastikan dari Vedas dan Psurana. Selain itu, mereka adalah ekspresi dari spiritual inspirasi saya yang terima dari Tuhan 


\section{DAFTAR KEPUSTAKAAN}

Admin, "Nabi Muhammad SAW Tercatat Dalam Kitab Suci Agama Hindu, Beliau Adalah Avatara yang Ditunggu-tunggu Umat Hindu," dalam http:// wmm.lensanws.blogspot.com/2016/10/nabimubammadsan-tercatat-dalam-kitb.html,

Admin, "Nabi Muhammad.SAW Tercatat Dalam Kitab Suci Agama Hindu, Beliau Adalah Avatara yang Ditunggu-tunggu Umat Hindu," dalam http:/ / wmw.lensanws.blogspot.com/2016/10/nabimubammadsan-tercatat-dalam-kitb.btml,

Anton Bakker dan Achmad Charis Zubar, Metodologi Penelitian Filsafat, (Yogyakarta: Kanisius, 2012)

Bumi Tanaya Sustika, "Nabi Muhammad Bukan Kalki Avatar," dalam bttp:/ / www.bumitanayasuastika.blo gspot.com/2009/10/nabi- mubammadbukan-kalki-avatar.btml, Diakses Tanggal 15 Februari 2020

Cudamani, Pengantar Agama Hindu, (Jakarta : Hanuman Sakti: 2013),

Jro Mangku Suardhana, "Hindu Menjawab: Kalki Awatara Bukanlah Nabi Muhammad."dalam http://www. dharmabuana09.blogspot.com/2016/07/hi ndu-menjawab-kalki-awatarabukanlah.html, Diakses Tanggal 15 Februari 2020.

Pembina Kerohanian Hindu Budha Disbintalad, Pokok-pokok Ajaran Hindu Dharma, (Jakarta: Disbintal Mabes TNI AD, 2013).

Rasyidi, Empat Kuliah Agama pada Perguruan Tinggi, (Jakarta: Bulan Bintang, 2011)

Sumber Data, Video Publikasi, Dakwah Chanel Kajian Ilmu, 2019.
Tim Penterjemah Hanuman Sakti, Awatara Inkarnasi Tuhan Yang Maha Esa, (Bali: PT. Hanuman Sakti Lisensi, 2012)

Tim Penterjemah Hanuman Sakti, Awatara Inkarnasi Tuhan Yang Maha Esa, hlm. 624. R. Soekmono, Pengantar Sejarah Kebudayaan Indonesia, (Jakarta : Gramedia Pustaka Utama, 2012), Jilid

Diakses Tanggal 15 Februari 2020.

Diakses Tanggal $\quad 15$ Februari 2020. 